\title{
UNDERSTANDING SEISMIC DESIGN CRITERIA FOR JAPANESE NUCLEAR POWER PLANTS
}

\author{
Y.J. Park and C.H. Hofmayer \\ Brookhaven National Laboratory \\ Upton, Long Island, New York 11973 \\ J.F. Costello \\ U.S. Nuclear Regulatory Commission \\ Washington, D.C. 20555
}

\begin{abstract}
This paper summarizes the results of recent survey studies on the seismic design practice for nuclear power plants in Japan. The seismic design codes and standards for both nuclear as well as nonnuclear structures have been reviewed and summarized. Some key documents for understanding Japanese seismic design criteria are also listed with brief descriptions. The paper highlights the design criteria to determine the seismic demand and component capacity in comparison with U.S. criteria, the background studies which have led to the current Japanese design criteria, and a survey of current research activities. More detailed technical descriptions are presented on the development of Japanese shear wall equations, design requirements for containment structures, and ductility requirements.
\end{abstract}

\section{INTRODUCTION}

As part of the USNRC efforts to understand Japanese earthquake engineering practice, a publication by the Japan Electric Association entitled JEAG 4601-1987 (Ref. [1]), "Technical Guidelines for Aseismic Design of Nuclear Power Plants", was translated and recently published as NUREG/CR6241 (Ref. [2]). The guidelines, which contain approximately 900 pages of technical material, provide a detailed description of the current Japanese seismic design methods, and can be considered to be a key document in understanding the seismic design criteria and practice for Japanese nuclear power plants.

In addition to the JEAG document, a large number of related documents published by the Ministry of International Trade and Industry (MITI) and the Architectural Institute of Japan (AIJ) have been reviewed to understand the seismic design criteria for various parts of nuclear power plants in Japan.

As a result of the survey studies, it was found that the Japanese design practice generally follows the ASME codes in designing components made of metallic materials, e.g., piping and vessels. However, differences between U.S. and Japanese practices have been found regarding the seismic design of concrete structures, particularly in shear wall design criteria. 


\section{DISCLAIMER}

Portions of this document may be illegible in electronic image products. Images are produced from the best available original document. 
This paper is intended to provide U.S. engineers with an overview of the current seismic design practice of nuclear power plants in Japan in some detail. The background studies for key design criteria for reactor buildings and containment structures are described based on the information collected in a recent survey.

\section{CODES AND STANDARDS}

Many of the design formulas for reactor buildings and containment structures have been adopted from non-nuclear standards with or without modifications. In the following, both non-nuclear and nuclear design codes and standards related to the seismic design of nuclear power plants are outlined.

The basic design requirements for non-nuclear building structures are defined in orders by the Ministry of Construction (MOC) (Ref [3]). The detailed design requirements, similar to the ASME and ACI codes, are provided by the following series of AIJ standards:

- Standard for Structural Calculation of Reinforced Concrete Structures, 1991 .......also known as "RC-Standard" (Ref. [4]).

- Design Standard for Steel Structures, 1973......also known as "Steel-Standard" (Ref. [5]).

- $\quad$ Standard for Structural Calculation of Steel Reinforced Concrete Structures, 1987 also known as "SRC-Standard" (Ref. [6]).

- Design Guidelines for Foundation Structures, 1988 ......also known as "Foundation Guidelines" (Ref. [7]).

The above AIJ standards are used primarily for the traditional allowable stress design required for the seismic design against moderate earthquakes. For the ultimate strength design, or for relatively new design approaches, such as base isolation systems, a series of AIJ "Guidelines" and "Recommendations" are available, e.g.,

- Design Guidelines for Earthquake Resistant Reinforced Concrete Buildings Based on Ultimate Strength Concept, 1990 (Ref. [8]).

- Design Guidelines for Base-Isolated Buildings, 1989 (Ref. [9]).

For the design/construction standards of nuclear facilities, the Ministry of International Trade and Industry (MIT) is the responsible governmental body. The design of nuclear facilities/equipment is based on the following MITI Orders and Notifications:

- $\quad$ MITI Order No. 62, "Technical Standards for Nuclear Power Plant Facilities", 1989 (Ref. [10]).

- $\quad$ MITI Notification No. 501, "Technical Standards for Structural Design of Nuclear Power Plant Equipment", 1992 (Ref. [11]).

- MITI Notification No. 452, "Technical Standards for Structural Design of Concrete Containment Structures of Nuclear Power Plant Facilities", 1990 (Ref. [12]). 
In addition, the basic design requirements for the seismic design of nuclear facilities are defined in the following guide:

- $\quad$ "Regulatory Guide for Aseismic Design of Nuclear Power Reactor Facilities", 1981, Japan Atomic Energy Commission (Ref. [13]).

The AIJ has also prepared the following recommendations:

- $\quad$ Recommendations for Structural Design of Reactor Buildings, 1988 (Ref. [14]).

- Recommendations for Structural Design of Nuclear Reactor Containment Structures, 1978 (Ref. [15]).

\section{SEISMIC REQUIREMENTS BY MOC}

One significant feature of the Japanese seismic codes by the MOC is the dual requirement that buildings should be evaluated both for moderate and severe earthquakes, as summarized below. For a moderate earthquake (basic seismic coefficient is $\mathrm{C}=0.2$ ), conventional allowable stress design is performed, which is similar to the UBC design requirements. However, for a severe earthquake (seismic force is $1.0 \mathrm{~g}$ in terms of $5 \%$ damped linear response), ultimate strength design should be performed which requires some type of nonlinear analysis to identify the failure mechanism of a building and the ductility requirements of components.

\begin{tabular}{cccc}
\hline Earthquake & Base Coefficient & Analysis & Component Evaluation \\
\hline Moderate & $\mathrm{C}=0.2$ & Linear & Short-Term Allowable* \\
Severe & $\mathrm{C}=1.0$ & Nonlinear & Ultimate Strength \\
\hline
\end{tabular}

$* 2 / 3 f_{c}^{\prime}$ for concrete, and yielding for steel.

In addition to the above basic seismic load requirements, limitations on the eccentricity and story drift (less than $1 / 200$ for $C=0.20$ ) are imposed on each story. The lateral seismic force, $Q_{i j}$, is defined as,

$$
Q_{i} \cdot D_{s} \cdot F_{e s} \cdot R_{t} \cdot A_{i} \cdot Z \cdot C \cdot W_{i}
$$

where

$D_{s} \quad=$ reduction factor due to ductility $(\approx 1 / \sqrt{2 \mu-1} ; 0.3$ for ductile frame, 0.5 for shear wall construction).

$F_{e s} \quad$ = penalty factor due to eccentricity ( 1.0 for no eccentricity).

$\mathbf{R}_{\mathbf{t}} \quad$ = spectral shape (function of building vibration frequency).

$\mathrm{A}_{\mathrm{i}} \quad$ = lateral shear distribution factor (function of story number, $\mathrm{i}$ ).

$\mathrm{Z} \quad=$ Zone coefficient.

C $\quad=0.2$ for moderate earthquake, $=1.0$ for severe earthquake.

$\mathrm{W}_{\mathrm{i}} \quad$ = weight of building above the $\mathrm{i}$-th story. 


\section{OVERVIEW OF DESIGN CRITERIA FOR NPP}

The seismic requirements of nuclear power facilities are determined according to the importance classification, As, A, B and C, as listed in Table 1 (Ref. [2]).

Table 1. Seismic Requirements

\begin{tabular}{|c|c|c|c|c|}
\hline & \multirow{2}{*}{$\begin{array}{l}\text { Aseismic Importance } \\
\text { Classification }\end{array}$} & \multirow{2}{*}{ Required Analysis } & \multicolumn{2}{|c|}{ Design Earthquake } \\
\hline & & & Horizontal & Vertical \\
\hline \multirow{4}{*}{$\begin{array}{c}\text { Building } \\
\& \\
\text { Structures }\end{array}$} & As & Dynamic & $\mathrm{S}_{2}$ & $1 / 2 S_{2}$ \\
\hline & As, $\mathrm{A}$ & $\begin{array}{l}\text { Dynamic } \\
\text { Static }\end{array}$ & $\begin{array}{c}S_{1} \\
3.0 C_{T}\end{array}$ & $\begin{array}{c}1 / 2 S_{1} \\
C_{v}\end{array}$ \\
\hline & B & Static & $1.5 \mathrm{C}_{\mathrm{I}}$ & --- \\
\hline & C & Static & $\mathrm{C}_{\mathrm{I}}$ & --- \\
\hline \multirow{4}{*}{$\begin{array}{c}\text { Equipment } \\
\& \\
\text { Piping }\end{array}$} & As & Dynamic & $\mathrm{S}_{2}$ & $1 / 2 S_{2}$ \\
\hline & As, $\mathrm{A}$ & $\begin{array}{c}\text { Dynamic } \\
\text { Static }\end{array}$ & $\begin{array}{c}S_{1} \\
3.6 C_{I} \\
\end{array}$ & $\begin{array}{l}1 / 2 \mathrm{~S}_{1} \\
1.2 \mathrm{C}_{\mathrm{v}} \\
\end{array}$ \\
\hline & B & Static & $1.8 \mathrm{C}_{\mathrm{I}}$ & -- \\
\hline & $\mathrm{C}$ & Static & $1.2 \mathrm{C}_{\mathrm{I}}$ & --- \\
\hline
\end{tabular}

Note: $S_{2}=$ extreme design earthquake

$\mathrm{S}_{1}=$ maximum design earthquake

$\mathrm{C}_{\mathrm{I}}=$ static seismic coefficient $(=0.2)$

Table 2 compares U.S. and Japanese design allowable stresses for reactor vessels and Class 1 piping. The Japanese $S_{1}$ design earthquake, which represents a moderate earthquake, is somewhat higher than the OBE of U.S. practice, and the $S_{2}$ earthquake, which represents a severe earthquake, is roughly equivalent to the SSE.

Table 3 lists some design damping values used in both countries. In general, the damping values used in Japan are lower than those used in the U.S. It should be noted that, since nonlinear analyses are required for the $\mathrm{S}_{2}$ earthquake, an additional hysteretic damping is also accounted for in the Japanese seismic design. 
Table 2. Comparison of Allowable Stresses Under Seismic Loads

(a) ASME Section III

\begin{tabular}{|l|l|l|}
\hline LOADING CONDITIONS & REACTOR VESSEL & CLASS 1 PIPING \\
\hline Level B Limit, Upset (OBE) & $1.5 \mathrm{~S}_{\mathrm{m}}$ & $1.8 \mathrm{~S}_{\mathrm{m}}, 1.5 \mathrm{~S}_{\mathrm{y}}$ \\
Level C Limit, Emergency & $1.8 \mathrm{~S}_{\mathrm{m}} 1.5 \mathrm{~S}_{\mathrm{y}}$ & $2.25 \mathrm{~S}_{\mathrm{m}} 1.8 \mathrm{~S}_{\mathrm{y}}$ \\
Level D Limit, Faulted (SSE) & $3.6 \mathrm{~S}_{\mathrm{m}} \mathrm{S}_{\mathrm{u}}$ & $3 \mathrm{~S}_{\mathrm{m}}, 2 \mathrm{~S}_{\mathrm{y}}$ \\
\hline
\end{tabular}

(b) JEAG 4601

\begin{tabular}{|c|c|c|}
\hline LOADING CONDITIONS & REACTOR VESSEL & PRIMARY PIPING \\
\hline \hline $\mathrm{S}_{1}$ Earthquake & $1.5 \mathrm{~S}_{\mathrm{y}} \mathrm{S}_{\mathrm{u}}$ & $2.25 \mathrm{~S}_{\mathrm{m}}$ \\
$\mathrm{S}_{2}$ Earthquake & $\mathrm{S}_{\mathrm{u}}$ & $3 \mathrm{~S}_{\mathrm{m}}$ \\
\hline
\end{tabular}

Table 3. Comparison of Damping (\%) Values

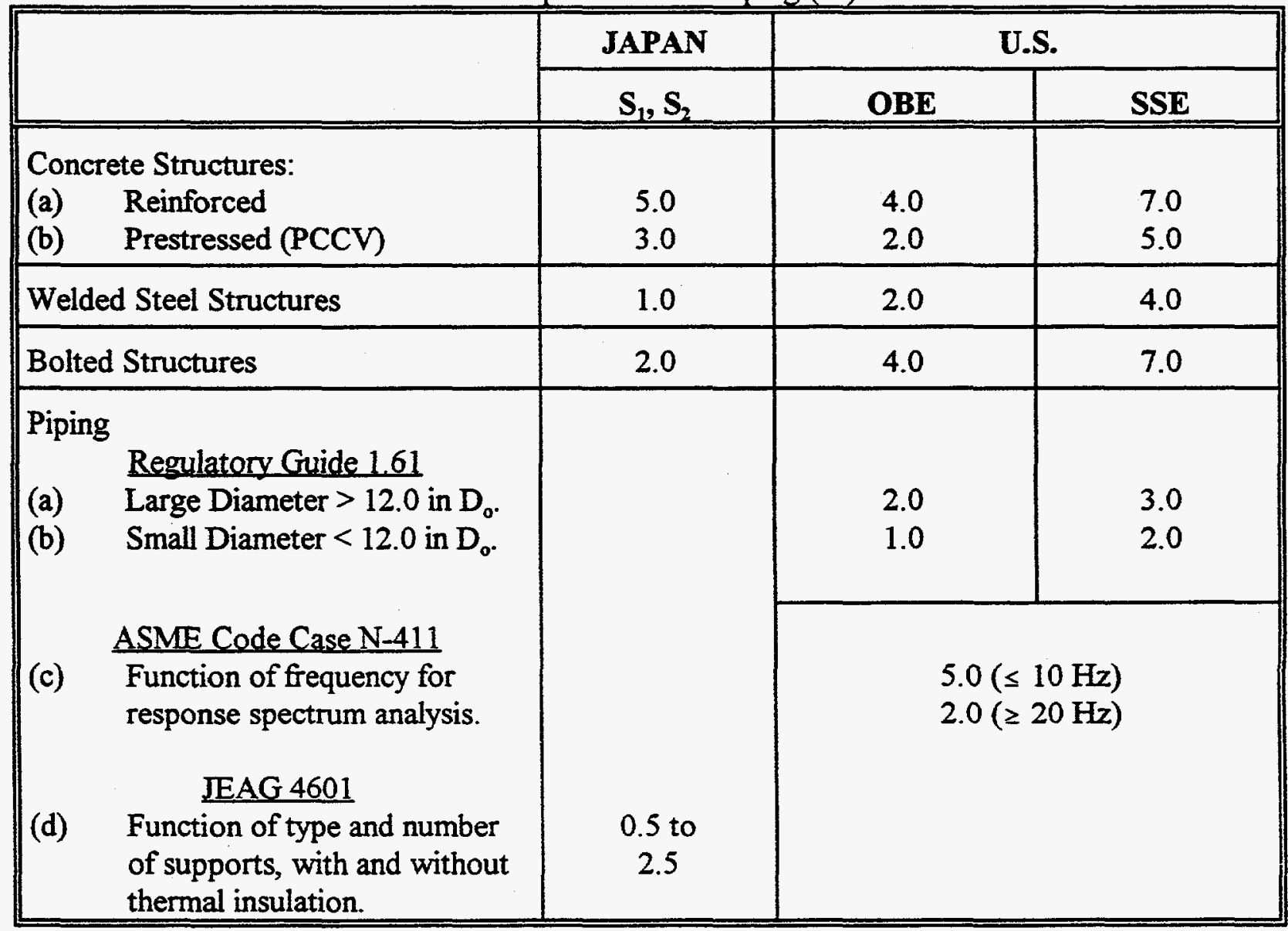




\section{DESIGN REQUTREMENTS FOR SHEAR WALL STRUCTURES}

The AIJ standard for RC structures (Ref. [4]), which can be considered as the equivalent of ACI-318, defines the allowable stresses for concrete structures as listed in Table 4. Figure 1 compares the short-term allowable shear stress from Table 4 with available test data. The upper and lower limits of ACI-318 $\left(3.5 \sqrt{f_{c}}\right.$ and $\left.1.9 \sqrt{f_{\varepsilon}}\right)$, are also shown in the figure.

Table 4. Allowable Stresses for Concrete (unit: $\mathrm{kg} / \mathrm{cm}^{2}$ )

\begin{tabular}{|c|c|c|c|}
\hline \multicolumn{2}{|c|}{ Long-term allowable (D.L. \& L.L.) } & \multicolumn{2}{|c|}{ Short-term allowable (Seismic Load) } \\
\hline Compression & Shear, $\mathrm{v}_{c}$ & Compression & Shear, $\mathrm{v}_{\mathrm{c}}$ \\
\hline $1 / 3 \mathrm{~F}_{\mathrm{c}}^{\prime}$ & $\min \left(\frac{F_{c}^{\cdot}}{30}, 5 \cdot \frac{F_{c}^{\cdot}}{100}\right)$ & $2 / 3 \mathrm{~F}_{c}^{\prime}$ & $\min \left(\frac{F_{c}^{\cdot}}{20}, 7.5,0.015 F_{c}^{\cdot}\right)$ \\
\hline
\end{tabular}

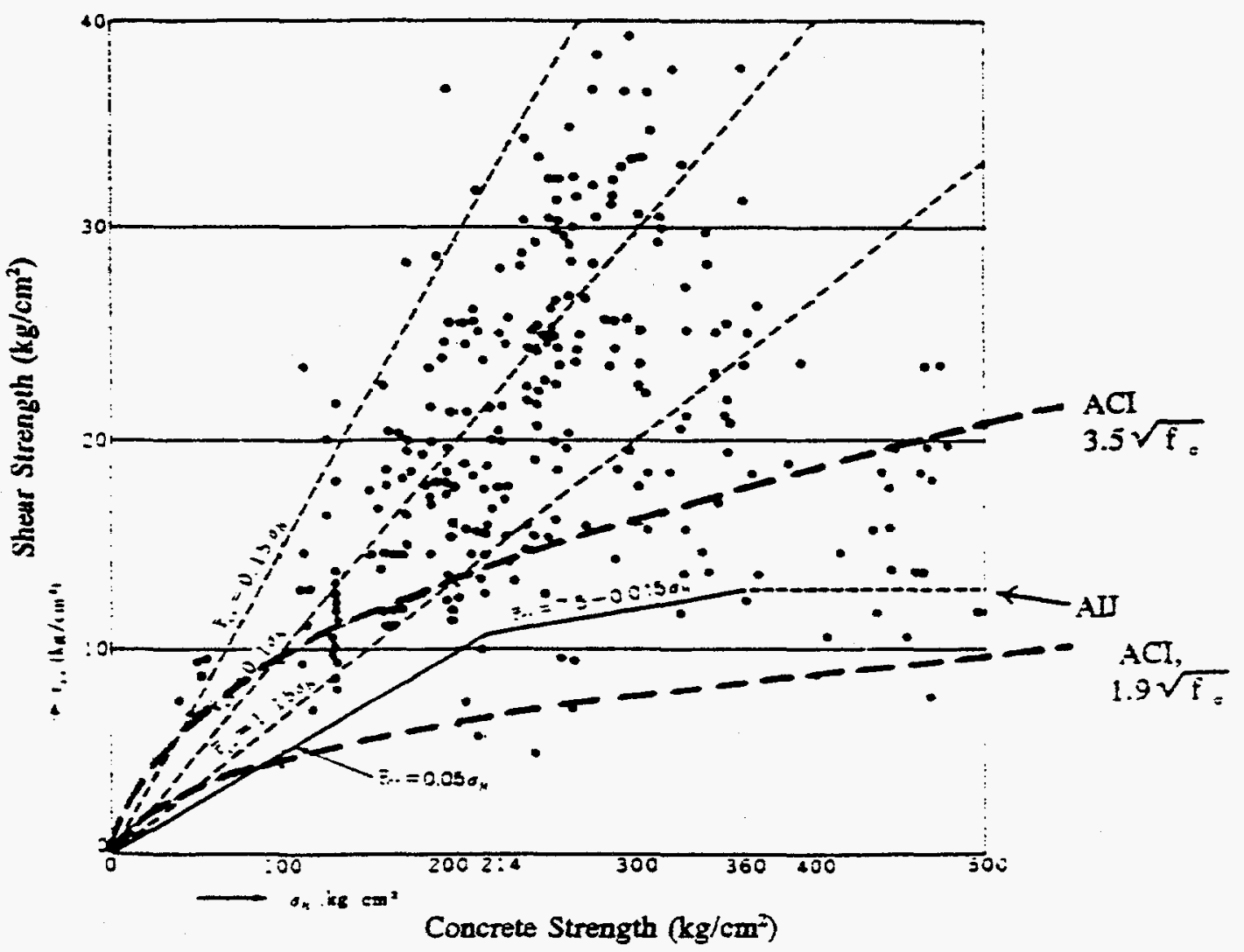

Figure 1. Shear Cracking Stress of Shear Walls Under Lateral Loads (Ref. [4]). 
The AIJ recommendations for the design of reactor buildings, which are also described in JEAG4601-1987 (Ref. [1], [2]), are based largely on the foregoing AIJ RC-Standard (Ref. [4]). In the recommendations, the concept of "allowable state" has been introduced, which is similar to the classification of levels A, B, C and D (i.e., normal, upset, emergency and faulted) in the ASME code.

\section{DEVELOPMENT OF SHEAR WALL EQUATIONS}

In the seismic design of reactor buildings, nonlinear dynamic analyses are generally required when considering the response to the $\mathrm{S}_{2}$ earthquake. Therefore, the shear wall equations are used not only for the component strength evaluation but also to determine the restoring force characteristics of the nonlinear structural models. The latter requirement necessitates the development of shear wall equations which can predict the ultimate capacity and the nonlinear deformation properties without bias or excessive conservatism. Currently, Hirosawa's equation is extensively used in the seismic design of reactor buildings. Hirosawa's equation, which is also extensively used for non-nuclear buildings, is also called the modified Arakawa's equation, as it was developed by modifying the shear strength equation for beams and columns by Arakawa (Ref. [4]). Some benchmark studies, which led to the current Japanese shear wall equations, are described below.

Arakawa's Study (1960) The current Japanese design criteria on the shear capacity of R.C. components are based on the studies by Arakawa (Ref. [16], [17]). Figure 2 shows a part of the correlation study to develop the following shear strength equation for reinforced concrete beams, which now is called the original Arakawa's equation:

$$
v_{u}\left(\mathrm{~kg} / \mathrm{cm}^{2}\right)=K_{u} \cdot K_{p} \frac{0.12\left(180+F_{c}\right)}{M / V d \cdot 0.12}+2.7 \sqrt{p_{w} \cdot f_{y}}
$$

in which $\quad \mathrm{K}_{\mathrm{u}} \quad=$ reduction factor for scale effect $(=0.72$ when $\mathrm{d}>40 \mathrm{~cm})$

$\mathrm{K}_{\mathrm{p}} \quad=0.82 \mathrm{p}_{\mathrm{t}}^{0.23}$

$\mathrm{p}_{\mathrm{t}} \quad=$ tension steel ratio in percent

$\mathrm{M} / \mathrm{Vd}=$ shear span ratio (replaced by 3 when larger than 3 )

$\mathrm{p}_{\mathrm{w}} \quad=$ stirnup ratio

The contribution of the reinforcement to the shear strength, $v_{s}$ or the second term of Eq. 2, was obtained empirically as illustrated in Figure 3. A total of 219 pairs of specimens, for which the shear reinforcement was the only parameter (i.e., one beam is shear reinforced and the other is not), were used to directly determine the contribution by the shear reinforcement as follows:

(Contribution by Shear Reinforcement) $=($ Shear Strength of Reinforced Beam) - (Shear Strength of Unreinforced Beam).

The results presented in Figure 3 indicate that the truss theory approximation, on which the current $\mathrm{ACI}$ equations are based, largely overestimates the shear contribution by steel. The data shown in Figures 2 and 3 , in fact, had a major impact on the subsequent design code development in Japan. 


\begin{tabular}{|c|c|c|c|c|c|}
\hline $\begin{array}{l}\bar{E} \\
\bar{g} \\
\overline{\bar{z}} \\
\overline{\bar{z}} \\
\bar{z}\end{array}$ & 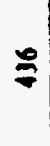 & $F$ & $\frac{a}{6}$ & $\bar{E}$ & $\stackrel{\Xi}{\Xi}$ \\
\hline$\stackrel{\underline{E}}{\underline{E}}$ & 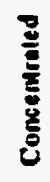 & $\begin{array}{l}\frac{D}{\frac{E}{z}} \\
\frac{E}{E} \\
\frac{E}{D}\end{array}$ & 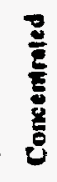 & 这 & \\
\hline 宔 & $\begin{array}{l}\frac{8}{2} \\
\frac{g}{2} \\
\text { g }\end{array}$ & & $\frac{5}{2}$ & & $\overline{\bar{z}}$ \\
\hline
\end{tabular}
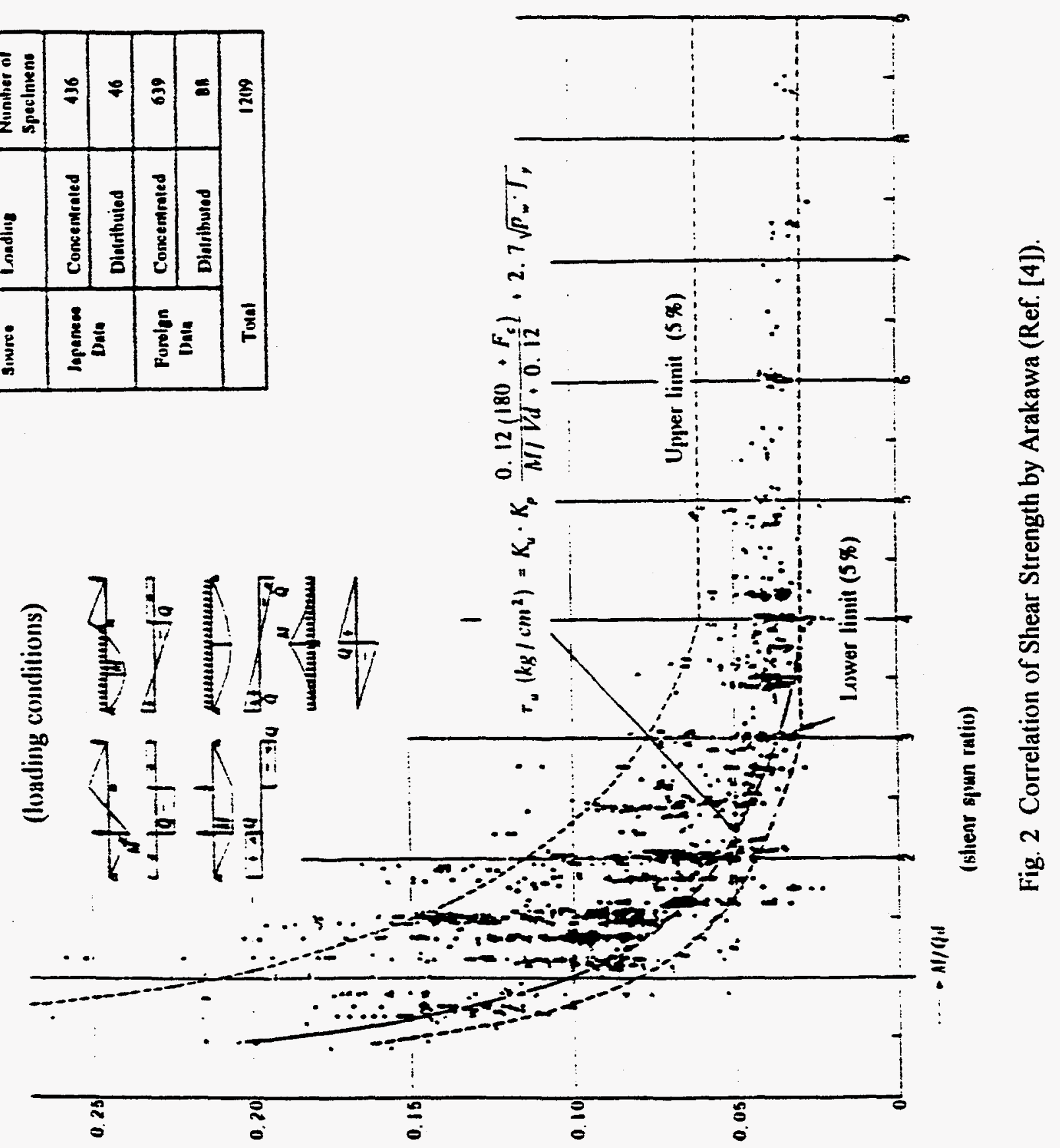

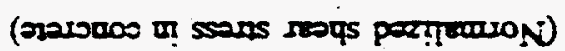




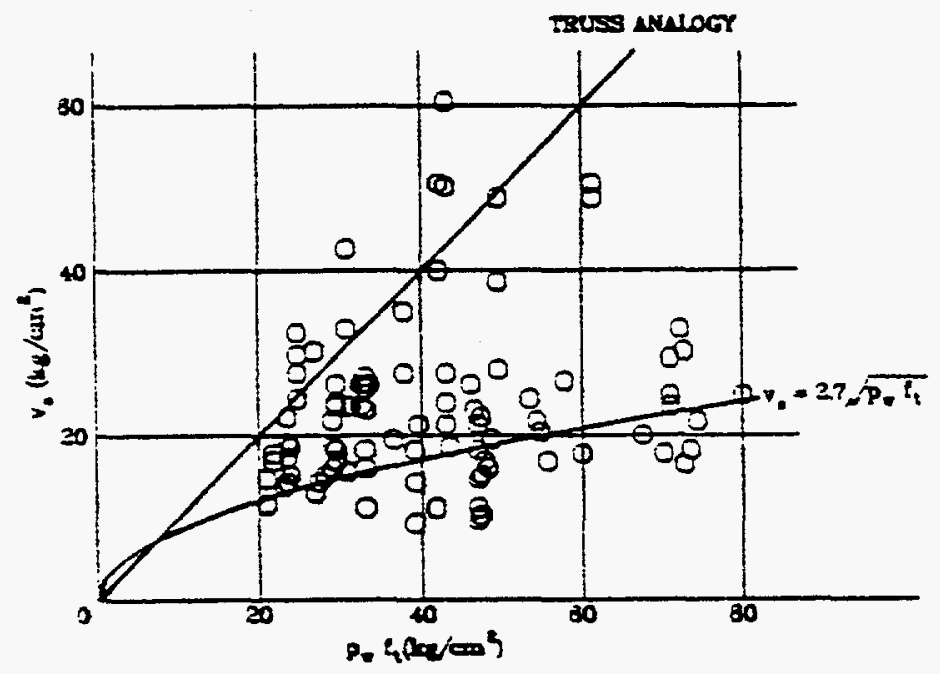

Figure 3. Contribution by Rebars to Shear Capacity (replotted based on the data in Ref. [16], components with $p_{w} f_{t}<20$ are excluded).

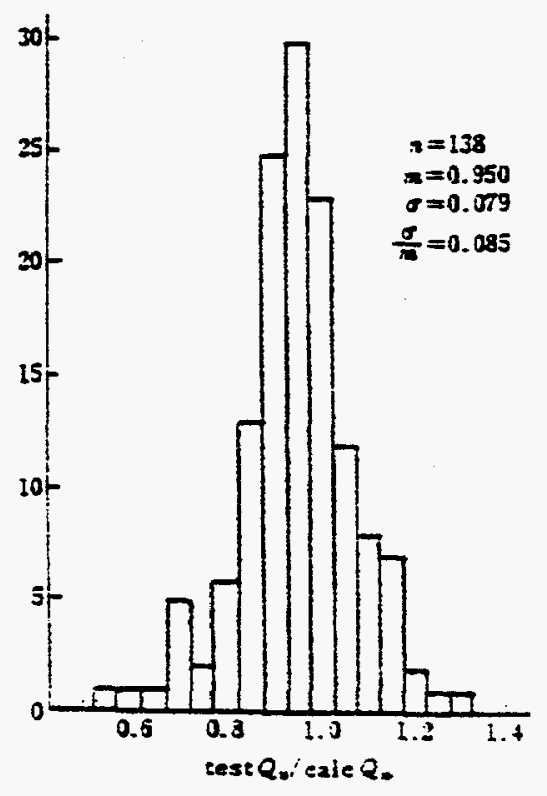

(a) AIJ equation (Eq. 1)

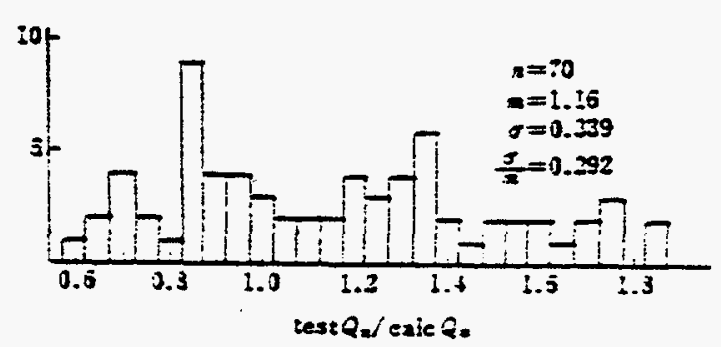

(b) ACI equation (Eq. 2)

Fig. 4. Histograms for the Ratios of Tests to Calculated Ultimate Shear Strength of R.C. Beams (Ref. [18]). 
The corresponding $\mathrm{ACI}$ equation is,

$$
\begin{aligned}
& V_{u}(b s)=V_{c}+\phi p_{w} \cdot f_{y} \cdot b d \\
& V_{c}(b s)=\phi\left(1.9 \sqrt{f_{c}}+2500 p_{w} \frac{V d}{M}\right) b d \leq 3.5 \sqrt{f_{c}^{b} b d}
\end{aligned}
$$

Figure 4 shows the results for correlation studies of the above shear strength equations (Ref. [18]). The ACI equations show a much larger scatter compared with the AIJ equation.

Hirosawa's Study on Shear Walls (1975) Hirosawa's equation is extensively used in Japan to calculate the ultimate shear strength of shear walls both for non-nuclear and nuclear power structures. The empirical equation was obtained by modifying the above Arakawa's equation (Ref. [19]):

$$
V_{u}(K g)=\left\{\frac{0.0679 p_{t}^{0.23}\left(F_{c}+180\right)}{\sqrt{M / V D+0.12}}+2.7 \sqrt{f_{y w} \cdot p_{w}}+0.1 \sigma_{0}\right\} b_{e} j
$$

where $b_{e} \quad=$ effective thickness of wall (when a wall has flanges, ' $b_{e}$ ' is calculated from a uniformthickness cross-section with equal area);

$\mathrm{j} \quad=0.83 \mathrm{D}(\mathrm{D}=$ total length of wall $)$

$p_{t}(\%)=100 A_{t} /\left(b_{\epsilon} \cdot j\right)$, tension axial steel ratio considering a wall as a column $\left(A_{t}=\right.$ total axial steel area in a flange);

M/VD = shear span ratio;

$\mathrm{p}_{\mathrm{w}} \quad=$ horizontal steel ratio using the effective thickness $b_{\mathrm{e}}$;

$\mathrm{F}_{\mathrm{c}} \quad=$ concrete strength $\left(\mathrm{kg} / \mathrm{cm}^{2}\right)$

$\mathrm{f}_{\mathrm{yw}} \quad=$ steel yield stress $\left(\mathrm{kg} / \mathrm{cm}^{2}\right)$

$\sigma_{\text {。 }} \quad=$ average axial stress $\left(\mathrm{kg} / \mathrm{cm}^{2}\right)$

Table 5 shows part of the correlation studies on this equation.

\section{DESIGN REQUIREMENTS FOR CONTAINMENT STRUCTURES}

The seismic design of concrete containment structures is performed based on MITI Notification No. 452 (Ref. [12]). This document, and in particular the background information upon which this standard is based, may be useful as the test results of large-scale containment structures are extensively utilized. Some unique features are highlighted herein, in the light of the U.S. practice for the seismic design of containment structures.

Loading State According to Notification No. 452, the structural design of containment structures is performed based on the "Loading States" shown in Table 6. 
Table 5. Correlation of Hirosawa's Equation (Ref. [19]).

\begin{tabular}{|c|c|c|c|c|}
\hline $\begin{array}{c}\text { Range of } \\
\text { Parameters }\end{array}$ & $\begin{array}{c}\text { Number of } \\
\text { Shear Walls }\end{array}$ & $\begin{array}{c}\text { Range } \\
\text { Vtest/Vcal }\end{array}$ & $\begin{array}{c}\text { Mean } \\
\text { Vtest/Vcal }\end{array}$ & $\begin{array}{c}\text { Standard } \\
\text { Deviation }\end{array}$ \\
\hline $0<\mathrm{M} / \mathrm{VD} \leq 0.75$ & 52 & $0.44 \sim 1.59$ & 0.90 & 0.23 \\
$0.75<\mathrm{M} / \mathrm{VD} \leq 1.0$ & 79 & $0.35 \sim 1.52$ & 0.92 & 0.21 \\
$1.0<\mathrm{M} / \mathrm{VD}$ & 37 & $0.54 \sim 1.24$ & 0.91 & 0.17 \\
\hline $0<\mathrm{t} / \mathrm{L}<0.3$ & 47 & $0.35 \sim 1.24$ & 0.81 & 0.18 \\
$0.3 \leq \mathrm{t} / \mathrm{L}<1.0$ & 84 & $0.54 \sim 1.59$ & 0.97 & 0.21 \\
$\mathrm{t} / \mathrm{L}=1.0$ & 37 & $0.64 \sim 1.19$ & 0.95 & 0.13 \\
\hline $\mathrm{p}_{\mathrm{w}}=0$ & 15 & $0.35 \sim 1.59$ & 0.99 & 0.39 \\
$0<\mathrm{p}_{\mathrm{w}}<0.4$ & 46 & $0.44 \sim 1.32$ & 0.89 & 0.23 \\
$0.4 \leq \mathrm{p}_{\mathrm{w}}<0.8$ & 50 & $0.53 \sim 1.50$ & 0.91 & 0.18 \\
$0.8 \leq \mathrm{p}_{\mathrm{w}}<1.2$ & 26 & $0.72 \sim 1.08$ & 0.94 & 0.11 \\
$1.2 \leq \mathrm{p}_{\mathrm{w}}$ & 31 & $0.70 \sim 1.22$ & 0.90 & 0.12 \\
\hline Total & 168 & $0.35 \sim 1.59$ & 0.92 & 0.21 \\
\hline
\end{tabular}

$\mathrm{M} / \mathrm{VD}=$ shear span ratio

$\mathrm{b}_{£} / \mathrm{D}=$ thickness ratio

$\mathrm{p}_{\mathrm{w}} \quad=$ horizontal shear reinforcement ratio

Table 6. Loading State for Containment Structures

\begin{tabular}{|c|l|c|c|c|}
\hline $\begin{array}{c}\text { Loading } \\
\text { States }\end{array}$ & $\begin{array}{c}\text { Plant } \\
\text { Condition }\end{array}$ & $\begin{array}{c}\text { Allowable Concrete } \\
\text { Compressive Stress }\end{array}$ & $\begin{array}{c}\text { Other Allowable } \\
\text { Stresses }\end{array}$ & $\begin{array}{c}\text { Thermal Stiffness } \\
\text { Reduction Factor }\end{array}$ \\
\cline { 1 - 2 } I & Normal & $1 / 3 \mathrm{~F}_{\mathrm{c}}$ & $\begin{array}{l}\text { Long-term allowable } \\
\text { (RC standard) }\end{array}$ & $1 / 2$ \\
\hline II & $\begin{array}{l}\text { Relief } \\
\text { valve/test }\end{array}$ & $2 / 3 \mathrm{~F}_{\mathrm{c}}$ & $\begin{array}{l}\text { Short-term allowable } \\
\text { (RC standard) }\end{array}$ & $1 / 3$ \\
\hline III & $\mathrm{S}_{1} \mathrm{EQ}$ & $\begin{array}{l}0.3 \% \text { for concrete } \\
0.5 \% \text { for steel }\end{array}$ & Neglect \\
\hline IV & $\mathrm{S}_{2} \mathrm{EQ} /$ accident & Strain limit & \\
\hline
\end{tabular}

Thermal Stress The evaluation of the thermal stresses is performed according to the following procedure.

- $\quad$ Reduce the elastic stiffness (i.e., Young's modulus) by a factor of $1 / 2$ for Loading States - I and II, and $1 / 3$ for Loading State - III, and calculate the thermal stresses.

- Calculate stresses for other loads using the original elastic stiffness.

- Combine the above stresses.

- For the Loading State - IV ( $\mathrm{S}_{2}$ earthquake and accident), the thermal stress is neglected. 


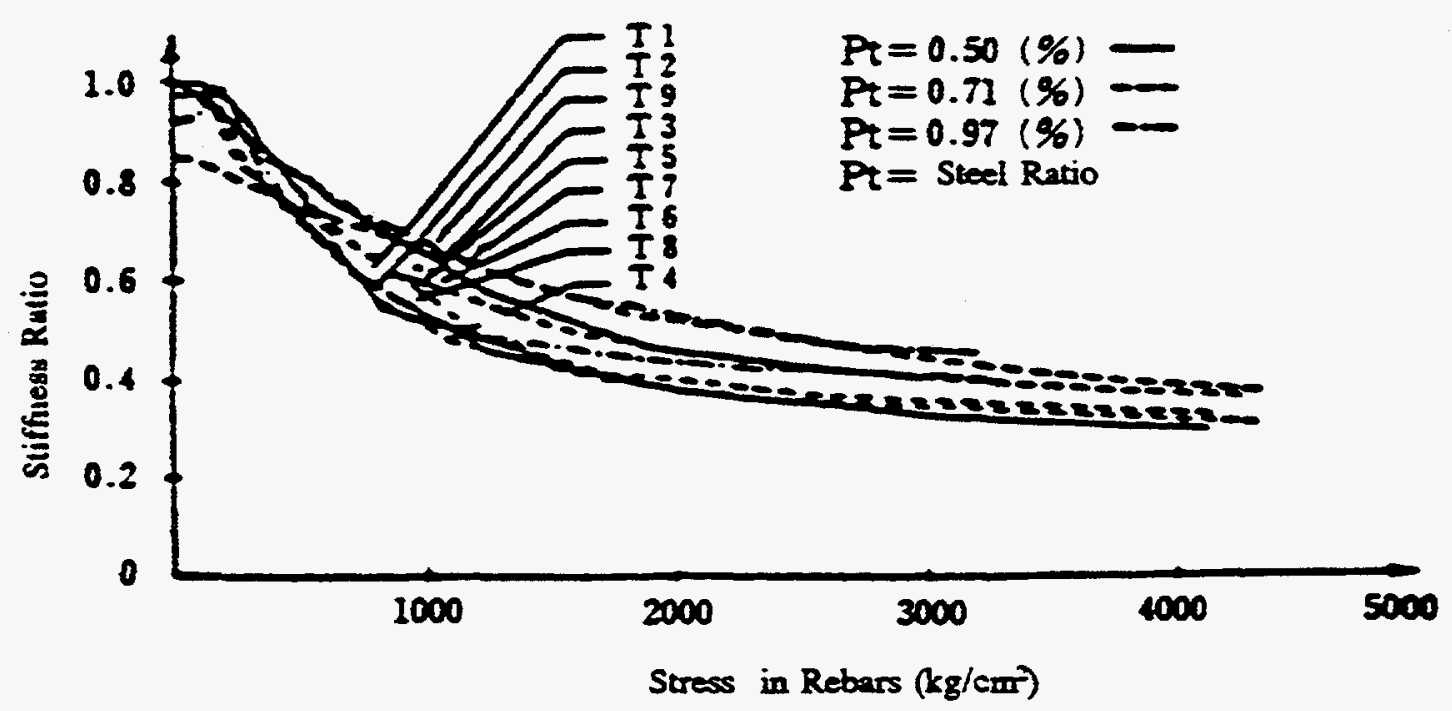

Figure 5. Reduction of Stiffness and Stress Level in Rebars (Ref. [14]).

Figure 5 shows the basis for the stiffness reduction factors of $1 / 2$ and $1 / 3$ shown in Table 6 . This figure is based on the results of tests of reinforced concrete components subjected to lateral loading under elevated temperature conditions. The stress level of the component is represented by the stress in rebars and the stiffness ratio is the secant stiffness at each stress level divided by the initial stiffness. The allowable stress for Loading States I \& II roughly corresponds to a stress of $2,000 \mathrm{~kg} / \mathrm{cm}^{2}(28.5$ $\mathrm{ksi}$ ), and for Loading State III, it is about $3,500 \mathrm{~kg} / \mathrm{cm}^{2}(49.8 \mathrm{ksi})$. Table 6 also indicates that the effects of thermal stresses can be neglected for the $S_{2}$ earthquake and accidental loadings both for containment structures and reactor buildings. This is based on the observation that the thermal stresses do not alter the ultimate strength of shear wall structures (Ref. [12]).

\section{DUCTILITY CAPACITY/REQUIREMENTS}

The allowable shear deformation for both reactor buildings and containment structures are defined to be $0.2 \%$ in radians (Ref. [1], [2], [12]). Based on a statistical analysis of available box-shaped and cylindrical shear wall structures, the minimum shear deformation capacity was estimated to be $0.4 \%$ in radians (Ref. [20]). Therefore, a safety factor of 2.0 is used to account for the large scatter associated with the shear deformation capacity.

Figure 6 shows the results of a study of available data on box-shaped and cylindrical shear walls by the authors. In the figure, the ultimate shear deformation capacity is plotted against the maximum shear stress. For high strength shear walls, the deformation capacity tends to decrease to about $0.4 \%$ in radians. However, for shear walls with less shear strength, a much higher ductility can be expected. The results of a similar study on shear deformation capacity are presented for both RCCV and PCCV structures in Ref. [12], in which the ultimate shear deformation capacity was plotted against the normalized steel ratio. According to this study, the ductility of containment structures tends to decrease as the steel ratio (therefore shear strength) increases. The minimum shear deformation 


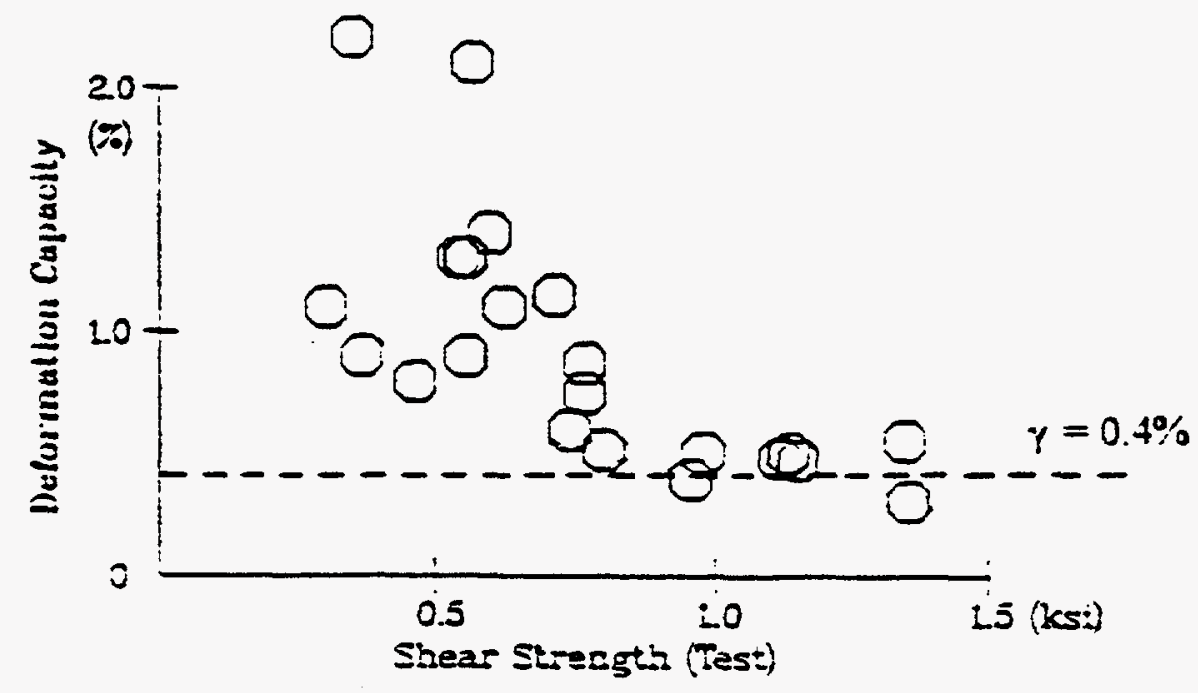

Figure 6. Shear Deformation Capacity of Box-Shaped and Cylindrical Shear Walls.

capacity for heavily reinforced containment structures converges to about $0.4 \%$ in radian. A more detailed statistical study on the shear deformation capacity of ordinary RC shear walls is also described in Ref. [18].

\section{SUMMARY AND CONCLUSIONS}

The current Japanese practice for seismic design, particularly that related to the seismic design of reactor buildings and containment structures, was reviewed in some detail as well as related research activities. There have been three decades of extensive experimental work, and judging from publications such as the transactions of the Annual Meeting of AIJ the experimental studies on components are continuing as the emphasis is being shifted more to newer design approaches, such as base isolation devices and pre-fabricated components.

The value of the wealth of accumulated information in Japan has been recognized by many prominent U.S. engineers. In fact, the test results of large-scale shear wall structures and pre-stressed components have been utilized in the fragility evaluation of nuclear reactor facilities, as they are the only available source of test data for these types of structures. The extent to which Japanese test data have been used by U.S. engineers, however, has been seriously limited due to the language barrier. Further efforts should be made to utilize the available information. The critical evaluation of existing nuclear facilities and the development of new design concepts require much more than structural analysis codes. The accumulated test results, mostly performed using modern testing facilities and earthquake-like loading conditions, should also be reviewed and evaluated in detail. 


\section{ACKNOWLEDGEMENTS}

The authors wish to thank K. Akino, S. Kawakami, T. Taira and N. Tanaka of NUPEC, S. Yoshizaki of Taisei Co., M. Kanechika of Kajima Co., and R. Shohara and Y. Takeuchi of Shimizu Co. for the information and cooperation in this survey study. The permission by the Architectural Institute of Japan to use the figures and tables from AIJ's publications is greatly appreciated.

The work presented in this paper was performed under the auspices of the U.S. Nuclear Regulatory Commission. The findings and opinions expressed in this paper are those of the authors, and do not necessarily reflect the views of the U.S. Nuclear Regulatory Commission or Brookhaven National Laboratory.

\section{REFERENCES}

[1] "Technical Guidelines for Aseismic Design of Nuclear Power Plants, JEAG 4601-1987, Japan Electric Association, 1987.

[2] Y.J. Park and C.H. Hofmayer, "Technical Guidelines for Aseismic Design of Nuclear Power Plants - Translation of JEAG 4601-1987, "NUREG/CR-6241, June 1994.

[3] "Guidelines and Commentary on Structural Design Calculations," Japan Architectural Center, 1981.

[4] "Standard for Structural Calculation of Reinforced Concrete Structures," AIJ, 1991.

[5] "Design Standard for Steel Structures," AIJ, 1973.

[6] "Standard for Structural Calculation of Steel Reinforced Concrete Structures," AIJ, 1987.

[7] "Design Guidelines for Foundation Structures," AIJ, 1988.

[8] "Design Guidelines for Earthquake Resistant Reinforced Concrete Buildings Based on Ultimate Strength Concept," AIJ, 1990.

[9] "Design Guidelines for Base-Isolated Buildings," AIJ, 1989.

[10] "Technical Standards for Nuclear Power Plant Facilities," MITI Order No. 62, ANRE/MITI, 1989.

[11] "Technical Standards for Structural Design of Nuclear Power Plant Equipment," MITI Notification No. 501, ANRE/MITI, 1992.

[12] "Technical Standards for Structural Design of Concrete Containment Structures of Nuclear Power Plant Facilities," MITI Notification No. 452, ANRE/MITI, 1990.

[13] "Regulatory Guide for Aseismic Design of Nuclear Power Reactor Facilities," Japan Atomic Energy Commission, 1981.

[14] "Recommendations for Structural Design of Reactor Buildings," AIJ, 1988.

[15] "Recommendations for Structural Design of Nuclear Reactor Containment Structures," AIJ, 1978.

[16] T. Arakawa, "Allowable Shear Stress and Shear Reinforcement of RC Beams," Concrete Journal, Japan, Vol. 8, No. 7, July 1970.

[17] K. Ohno and T. Arakawa, "Study on Shear Resistance of Reinforced Concrete Beams," Transaction of AIJ, No. 66, October 1960. 
[18] "Data for Ultimate Strength Design of Reinforced Concrete Structures," AIJ, 1987.

[19] M. Hirosawa, "Past Experimental Results on Reinforced Concrete Shear Walls and Analysis on Them," Building Research Institute, Ministry of Construction of Japan, March 1975.

[20] T. Setogawa, "Allowable Limit of Shear Walls in Reactor Buildings," Annual Meeting of AIJ, pp. 2091-2092, Oct. 1987.

\section{DISCLAIMER}

This report was prepared as an account of work sponsored by an agency of the United States Government. Neither the United States Government nor any agency thereof, nor any of their employees, makes any warranty, express or implied, or assumes any legal liability or responsibility for the accuracy, completeness, or usefulness of any information, apparatus, product, or process disclosed, or represents that its use would not infringe privately owned rights. Reference herein to any specific commercial product, process, or service by trade name, trademark, manufacturer, or otherwise does not necessarily constitute or imply its endorsement, recommendation, or favoring by the United States Government or any agency thereof. The views and opinions of authors expressed herein do not necessarily state or reflect those of the United States Government or any agency thereof. 